\title{
HISTOPATHOLOGICAL EFFECT OF CERTAIN HEAVY METALS ON THE MOSQUITO VECTOR CULEX PIPIENS L. (DIPTERA: CULICIDAE)
}

MOHAMAD A. FOUDA , MOSTAFA I. HASSAN, TAREK M. Y. EL-SHEIKH, ABD-ELHAMED A. ABD-ELGHAPHAR AND AHMED I. HASABALLAH

Department of Zoology, Faculty of Science (boys), Al-Azhar University, Nasr City, Cairo, Egypt.

\begin{abstract}
In the laboratory, histopathological effects of heavy metals in the form of cadmium chloride, copper sulphate, lead nitrate and mercuric nitrate were tested against the adults resulted from the $2^{\text {nd }}$ larval instar of $C$. pipiens treatment with the $\operatorname{LC}_{50 \text { s }}(0.11,5.1,45.4$ and $0.44 \mathrm{ppm}$ ) to study their effect on certain histological organs such as ovary, testis and fat body. The histological examinations of ovaries in heavy metals-treated C. pipiens females showed a reduction in the number of developed oocytes and degeneration of a great number of oocytes. The highest reduction and damage were induced by $\mathrm{Cd}$ and $\mathrm{Hg}$. The present study also showed damage and reduction in spermatogonia and spermatocytes in heavy metals-treated $C$. pipiens males. The highest reduction and abnormality were caused by $\mathrm{Cd}$ and $\mathrm{Hg}$. In addition, the present study showed alteration and abnormality of fat body in heavy metals-treated mosquitoes. It is clear from the results obtained in this study that the presence of such elements in the ecosystem water for Culex mosquitoes as possible to contribute to the reduction of mosquito breeding.
\end{abstract}

Key words: Heavy metals, Ovary, Testis, Fat body, C. pipiens.

\section{Introduction}

Heavy metal pollution of aquatic ecosystems is an important environmental problem. Aquatic ecosystems are typically monitored for pollution by heavy metals using chemical or biological assays (Wong and Dixon, 1995; Yang and Rauckmann, 1987). Although sensitive, chemical measurements of heavy metals in water do not provide information about the bioavailability of a heavy metal, the biological impact of heavy metals on aquatic insects has been extensively studied in nature and in the laboratory (e.g., Cain et al., 1992; Clements and Kiffney, 1994; Dallinger, 1994; Postma and Davids, 1995). Aquatic insects accumulate heavy metals and have long been exploited as indicator species of environmental pollution and for bioassays of pollutants (Hare, 1992). Aquatic insects are sensitive bioreporters of heavy metal contamination because exposure occurs during critical stages of insect development such as embryogenesis, larval development, and pupation. In addition to mortality, exposure of aquatic insects to heavy metals can 
result in changes in eclosion rates, locomotion, behavior, oviposition, and mating (Rayms-Keller et al., 1998). However, only scattered information on effects of heavy metal stress on metabolism, structure and function of the reproductive organs in mosquitoes is available. The fecundity of insects is also negatively affected by environmental toxins, including heavy metals (Devkota and Schmidt, 1999). The negative effect of $\mathrm{Cd}$ on reproduction was due to an inhibition of vitellogenesis, $\mathrm{Vg}$ polypeptide levels were studied in Oncopeltus fasciatus females exposed to $\mathrm{Cd}$ (Cervera et al., 2006).

Mosquitoes serve as vectors of many vertebrate blood pathogens; Culex pipiens is a very common mosquito species in Egypt and is the predominant vector of Wuchereria bancrofti that causes filariasis or elephantiasis in humans (Khalil et al., 1930 and Gad et al., 1996), Rift Valley fever virus (Meagan et al., 1980; Darwish and Hoogstraal, 1981) and West Nile virus (Pelah et al., 2002).

The present investigation was carried out to study the histopathological effects of heavy metals tested ions namely; cadmium $(\mathrm{Cd})$, copper $(\mathrm{Cu})$, lead $(\mathrm{Pb})$ and mercury $(\mathrm{Hg})$ on the reproductive organs in females and males at the level of oogenesis and spermatogenesis, respectively.

\section{Materials And Methods}

\section{1- Origin and laboratory maintenance of the mosquito colony:}

Mosquitoes used in this study were Culex pipiens L., they were collected from Abu Rawash, Giza governorate, then were reared for several generations, in the insectary of Medical Entomology at the Department of Zoology, Faculty of Science, Al-Azhar University, under controlled conditions at temperature of $27 \pm 2{ }^{\circ} \mathrm{C}$, relative humidity $70 \pm 10 \%$ and $12-12$ light-dark regime. Adult mosquitoes were kept in (30 x 30 x $30 \mathrm{~cm}$ ) wooden cages and daily provided with sponge pieces soaked in $10 \%$ sucrose solution for a period of 3-4 days after emergence. After this period the females were allowed to take a blood meal from a pigeon host, which is necessary for laying eggs (anautogeny). Plastic cup oviposition $(15 \times 15 \mathrm{~cm})$ containing dechlorinated tap water was placed in the cage.

The resulting egg were rafts picked up from the plastic dish, and transferred into plastic pans ( $25 \times 30 \times 15 \mathrm{~cm}$ ) containing 3 liters of tap water. The hatching larvae were provided daily with fish food as a diet. This diet was found to be the most 
preferable food for the larval development and a well female fecundity, (Kasap and Demirhan, 1992).

\section{2- Heavy metals tested:}

The salts of heavy metals used in this work were; cadmium chloride $\left(\mathrm{CdCl}_{2}\right)$, copper sulphate $\left(\mathrm{CuSO}_{4}\right)$, lead nitrate $\left(\mathrm{Pb}\left(\mathrm{NO}_{3}\right)_{2}\right)$ and mercuric nitrate $\left(\mathrm{Hg}\left(\mathrm{NO}_{3}\right)_{2}\right)$, each of these salts was dissolved in distilled water (dist.) to make a stock solution of $1000 \mathrm{ppm}$. The stock solution was then diluted to make a series of different concentrations.

The concentrations were: A) $\mathbf{C d C l}$ : $0.05,0.1,0.15,0.2$ and 0.3 ppm. B) $\mathbf{C u S O}$ : 1, 2, 4, 8 and 10 ppm. C) Pb (NO $\mathbf{N O}_{2}:$ 8, 16, 32, 50 and 75 ppm. D) $\mathbf{H g}\left(\mathbf{N O}_{3}\right)_{2}:$ 0.1, $0.2,0.5,0.7$ and $1 \mathrm{ppm}$.

\section{3- Experimental bioassay:}

In order to study the toxicity of these heavy metals, different range of concentrations of each heavy metal salt was used. The $2^{\text {nd }}$ instar larvae were collected from the established colony and placed in plastic cup its diameter was 12 $\mathrm{cm}$ and its hight was $7 \mathrm{~cm}$ containing $250 \mathrm{ml}$ of the metal salt solution as recommended by (WHO). Control larvae were placed in cups contained $250 \mathrm{ml}$ dechlorinatedtap water ( $252^{\text {nd }}$ instar larvae/cup). At least three replicates were used in each experiment. All plastic cups were incubated under controlled conditions at temperature of $27 \pm 2{ }^{\circ} \mathrm{C}$, relative humidity $70 \pm 10 \%$ and $12-12$ light-dark regime.

\section{4- Histological technique:}

The adult males and females resulted from larvae treated with the $\mathrm{LC}_{50}$ of each heavy metal salts tested were used in making longitudinal and parasagital sections to study the histopathological effects in gonads and fat body. The different sections were carried out after 3 days from feeding on blood in case of females or sugar solution $10 \%$ in case of males. The histological technique was that of Scott et al. (1993).

\section{Results}

\section{Histopathological effects of heavy metals on C. pipiens:}

Histopathological effects of heavy metals namely, cadmium, copper, lead and mercury on ovarian development and spermiogenesis as well as fat bodies in $C$. pipiens were studied. The larvae were treated with the $\mathrm{LC}_{50}$ of $\mathrm{CdCl}_{2}(0.11)$, 
$\mathrm{CuSO}_{4}$, (5.1), $\mathrm{Pb}\left(\mathrm{NO}_{3}\right)_{2}$ (45.4) and $\mathrm{Hg}\left(\mathrm{NO}_{3}\right)_{2}(0.44 \mathrm{ppm})$ and the resulted male and female adults were dissected 3 days post feeding in order to examine the ovarian development, spermatogenesis and fat bodies.

\section{Ovary:}

As shown from figs. (1-7) by $72 \mathrm{~h}$ (PBM), the ovaries of normal untreated females occupied nearly most of the abdominal cavity. They consisted of well developed oocytes (eggs), where the yolk mass increased and the egg increased in size and became nearly elongated. In contrast, the histological examination of ovaries of heavy metals-treated females generally showed a reduction in the number of developed oocytes. Also signs of degenerative processes in oocytes were observed (Figs.4-7). However, the highest reduction and damage were induced by cadmium followed by mercury and lead (Figs.4, 6 and 7).

\section{Testis:}

Figures (8 and 9) show the typical synchrony of the normal testis follicle in the normal untreated males. Each testis follicle contains a successions of zones in which the sex cells are in different stages of development. These are (i) the germarium or zone of spermatogonia, (ii) zone of spermatocytes, (iii) zone of maturation and reduction (zone of spermatids formation) and (iv) zone of transformation (zone of spermatozoa formation). However, this synchrony was lost in the heavy metalstreated males, where damage at the level of spermatogonia and spermatocytes, and alteration of spermiogenesis were observed. (Figs. 10-13). As in treated females, cadmium, mercury and lead showed the highest damage, where they caused high reduction in spermatozoa formation and abnormality (Figs. 10, 12 and 13). On the contrary, copper showed the lowest alteration and damage of spermiogenesis. (Fig. 11).

\section{Fat body:}

The fat body of normal untreated mosquito adults consists of loosely aggregated or compact masses of cells which arranged in irregular strands or sheets (Fig. 14). The trophocytes which represent the greater part of the fat body are vacuolated and distended by stores of glycogen, fat or protein (Fig. 14). In the contrary, in the fat body of heavy metals- treated mosquitoes, alteration and abnormality were observed. The volume of fat body was reduced, devoid of lipid droplets within the 
fat cells and vacuoles between the fat cell sheet were appeared (Figs. 15-18). The most destructive effect was caused by mercury, cadmium and lead. 


\section{Discussion}

The mortality suffered by C. pipiens larvae showed high sensitivity to heavy metals contamination based on $\mathrm{LC}_{50}$, the toxicity values of the heavy metals tested were arranged in descending order as follows: $\mathrm{Cd}>\mathrm{Hg}>\mathrm{Cu}>\mathrm{Pb}$. Lead seemed to be less toxic than other metals.

These results are similar to that demonstrated by Zhang et al. (2001) against the German cockroach, Blattella germanica. They referred the lower mortality induced by lead to its high accumulation in the insects. However, it is well known that arthropods are able to detoxify metals by bounding specific proteins such as the metallothionines (Bouquegneau et al., 1985, Kohler and Albertti, 1992).

Investigations on various lepidopteran species have shown developmental retardation and growth reduction as well as a depression or inhibition of reproduction due to metal stress (Zelenayora, 1986).

The histological examinations of ovaries in heavy metals-treated C. pipiens females showed a reduction in the number of developed oocytes and degeneration of a great number of oocytes. The highest reduction and damage were induced by $\mathrm{Cd}$ and $\mathrm{Hg}$. Also, the present study showed damage and reduction in spermatogonia and spermatocytes in heavy metals-treated $C$. pipiens males. The highest reduction and abnormality were caused by $\mathrm{Cd}$ and $\mathrm{Hg}$. In addition, the present study showed alteration and abnormality of fat body in heavy metals-treated mosquitoes. These observations are similar to that obtained by Martoja et al. (1983) in Cd- and Hgtreated Locusta migratoria, Zhang et al. (2001) in B. germanica contaminated with $\mathrm{Cd}, \mathrm{Hg}$ and $\mathrm{Pb}$. Cervera et al. (2004) studied the effect of $\mathrm{Cd}$ on Oncopeltus fasciatus (Heteroptera: Lygaeidae) and they found that, Cd exposure decreased the oviposition rate, fecundity and fertility of females, and also the viability of their progeny. Moreover, the negative effect of Cd on reproduction was due to an inhibition of vitellogenesis (Cervera et al. 2006). These observations are similar to that obtained by the present authors El-Sheikh et al. (2010).

Besides, damage in oocytes and spermatocytes, a delay in the maturation of gonads was observed in the heavy metals-treated mosquitoes. The present results confirm the data obtained by El-Sheikh et al. (2010). They referred the low fecundity and fertility of $C$. pipiens resulted from larval treatement with the $\mathrm{LC}_{50}$ of $\mathrm{Cd}, \mathrm{Pb}$ and $\mathrm{Hg}$. 
As a conclusion, heavy metals disturb the function of male and female reproductive organs, where they caused damage and abnormality in oocytes and spermatocytes. The highest effect was induced by $\mathrm{Cd}$ followed by $\mathrm{Hg}$ and $\mathrm{Pb}$. 


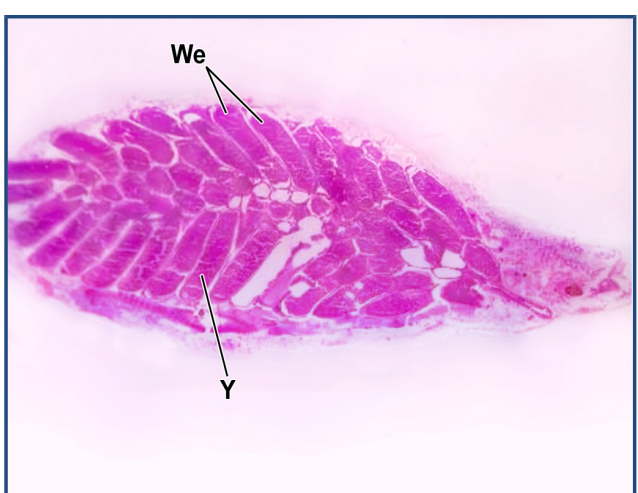

Fig. (1): Parasagital section in the ovary of a control mature female, C. pipiens. (x 100). We (Well developed egg), y (yolk).

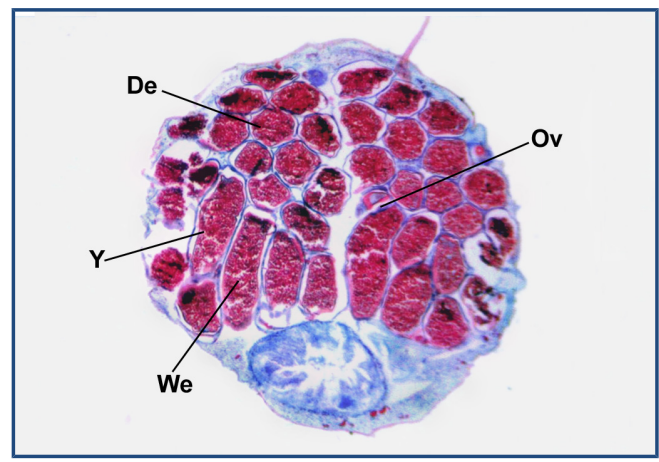

Fig. (2): Longitudinal section in the ovary of a control mature female, C. pipiens. (x 100). Ov (ovary), We (well developed egg), Y (yolk), De (developed egg).

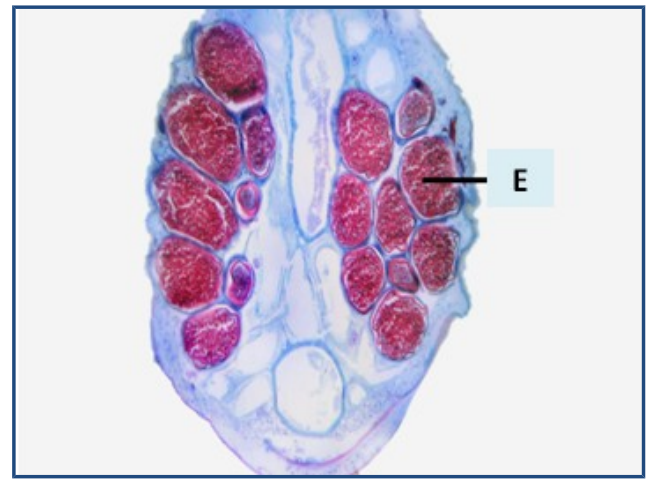

Fig. (3): Parasagital section in the ovary of a mature female, C. pipiens treated with the $\mathrm{LC}_{50}$ of $\mathrm{CdCl}_{2}$ showing the reduction of egg numbers. (x 100), E (Egg). 


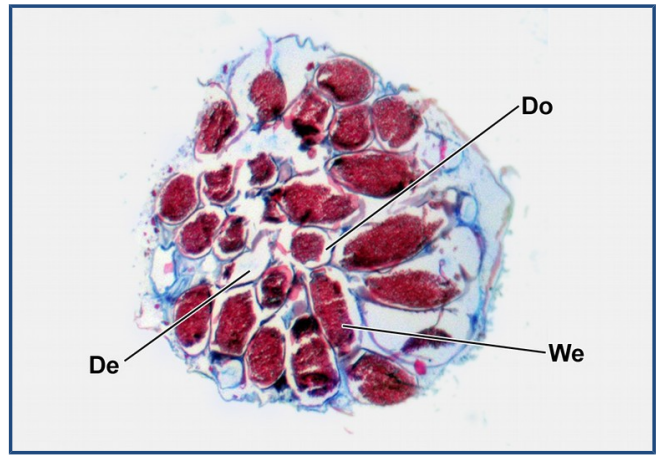

Fig. (4): Longitudinal section in the ovary of a mature female, C. pipiens treated with the $\mathrm{LC}_{50}$ of $\mathrm{CdCl}_{2}$ showing the reduction of mature eggs and the great number of degenerated eggs. (x 100). De (degenerated egg) We (well developed egg), Do (degenerated oocyte).

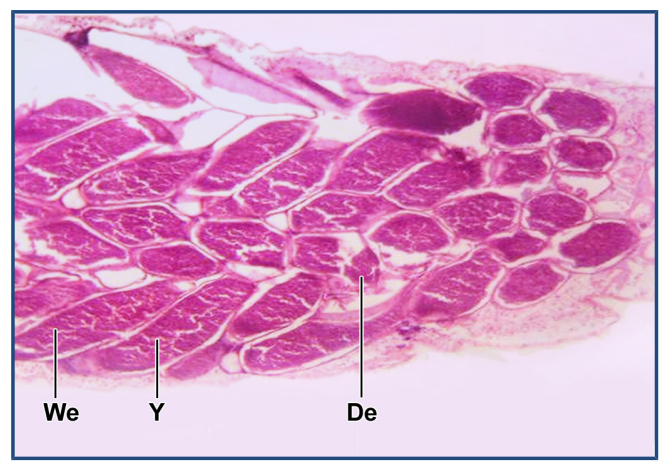

Fig. (5): Parasagital section in the ovary of a mature female, $C$. pipiens treated with the $\mathrm{LC}_{50}$ of $\mathrm{CuSO}_{4}$. (x 100). Y (yolk), We (well developed egg), De (degenerated egg).

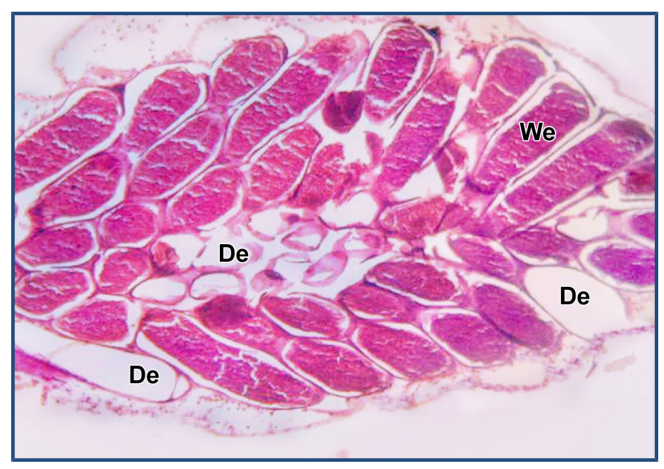


Fig. (6): Parasagital section in the ovary of a mature female, C. pipiens treated with the $\mathrm{LC}_{50}$ of $\mathrm{Pb}\left(\mathrm{NO}_{3}\right)_{2}$. (x 100). We (well developed egg), De (degenerated egg).

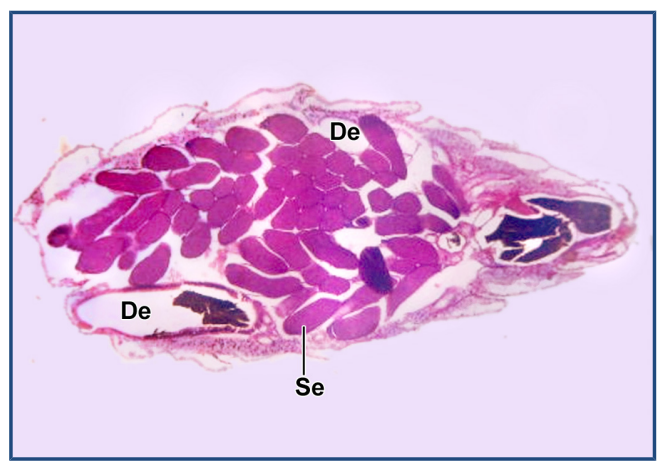

Fig. (7): Parasagital section in the ovary of a mature female, C. pipiens treated with the $\mathrm{LC}_{50}$ of $\mathrm{Hg}\left(\mathrm{NO}_{3}\right)_{2}$. (x 100). Se (small egg), De (degenerated egg).

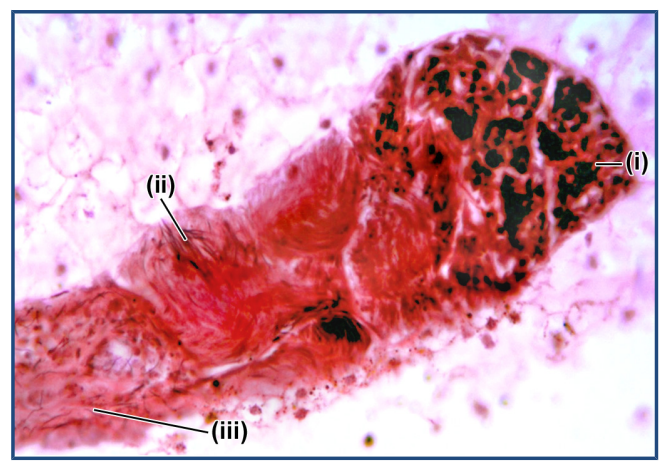

Fig. (8): Longitudinal section in testis follicle of normal (control) mature male of C. pipiens showing the different zones of testis follicle. (x 400), zone of spermatogonia (i), zone of spermatocytes (ii), zone of spermatids (iii).

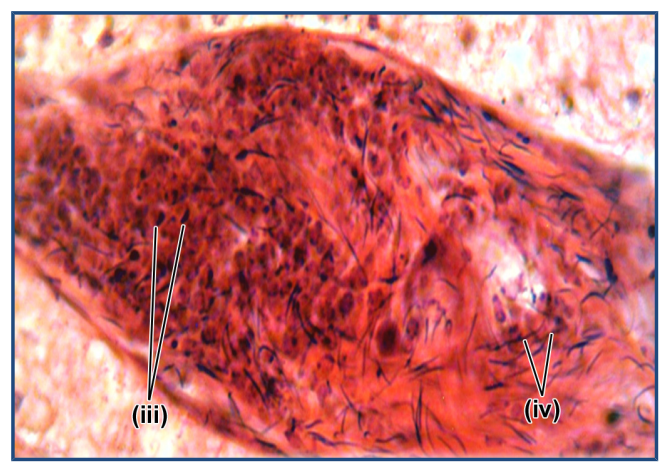


Fig. (9): Longitudinal section in testis follicle of normal (control) mature male of C. pipiens showing the different zones of testis follicle. (x 400). Zone of spermatozoa (iv), zone of spermatids (iii).

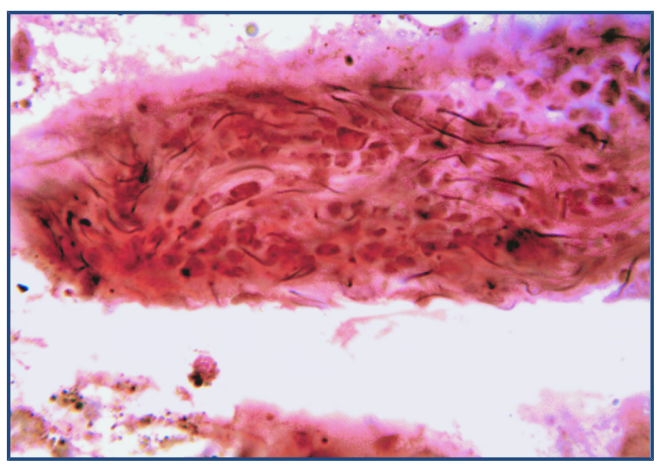

Fig. (10): Longitudinal section in testis follicle of cadmium-treated mature male of C. pipiens showing the abnormality of spermatozoa zone (iv), and the low numbers of spermatozoa. (x 400).

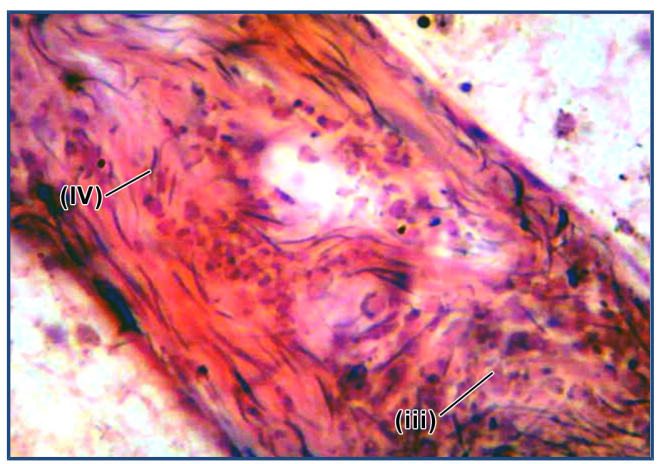

Fig. (11): Longitudinal section in testis follicle of copper-treated mature male of C. pipiens. (x 400). Zone of spermatozoa (iv), zone of spermatids (iii).

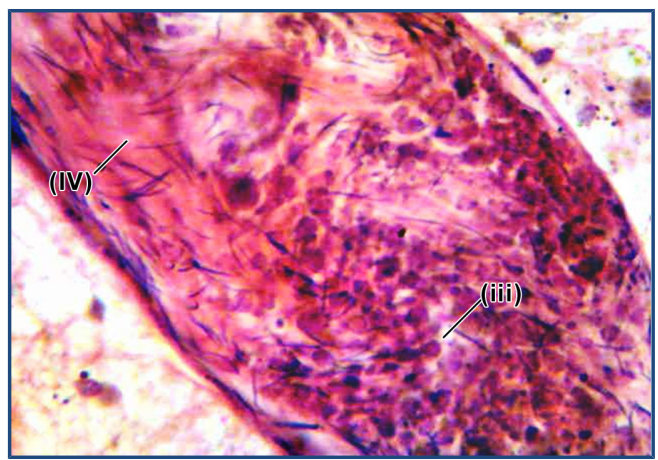


Fig. (12): Longitudinal section in testis follicle of lead-treated mature male of $C$. pipiens showing the abnormality of spermatids (zone iii) and the reduced number of spermatozoa (zone iv) (x 400).

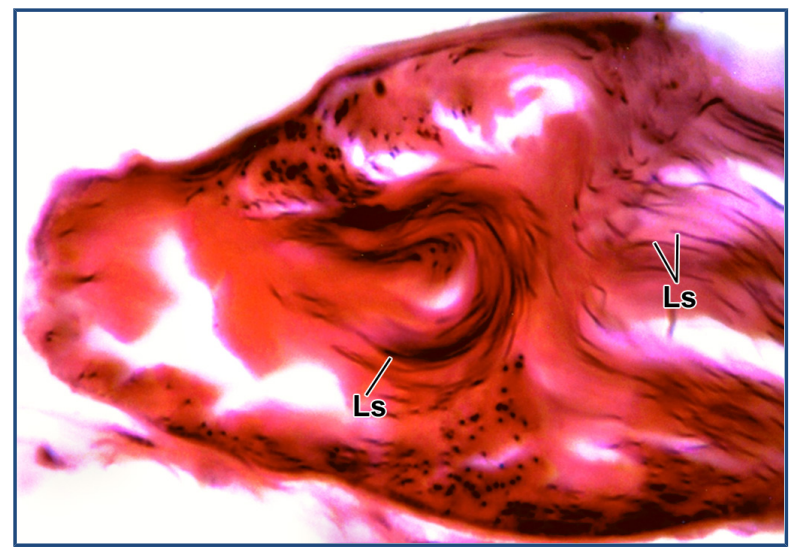

Fig. (13): Longitudinal section in testis follicle of mercury-treated mature male of $C$. pipiens showing the abnormality of the formed spermatozoa (x 400). Ls (long tailed spermatozoa).
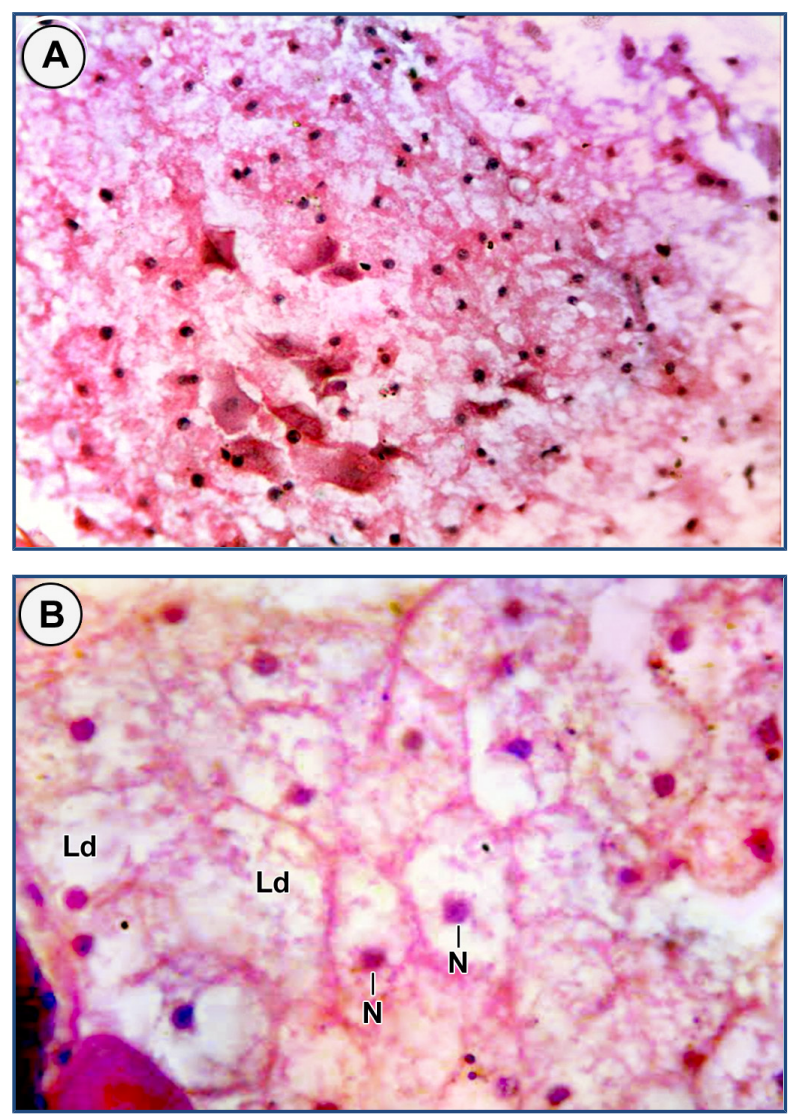
Fig. (14): Fat body of a control untreated mature female, C. pipiens. A (x 100), B (x 400). N (nucleus), Ld (lipid droplet).

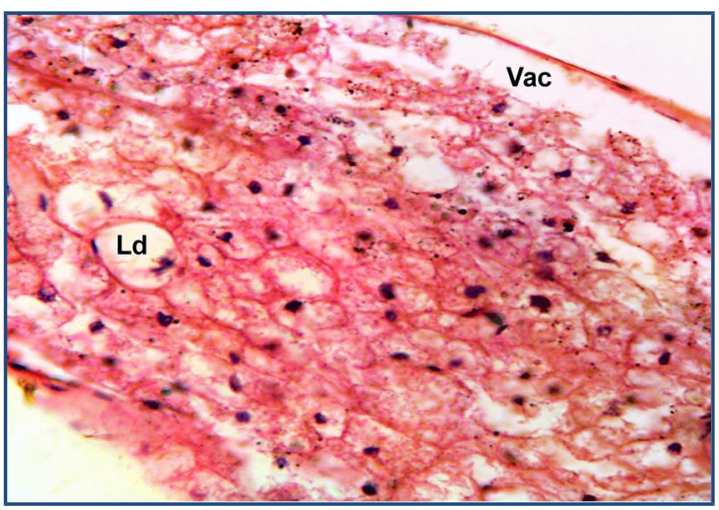

Fig. (15): Fat body of a cadmium-treated mature female, C. pipiens (x 100), Vac (vacuole), Ld (lipid droplet).

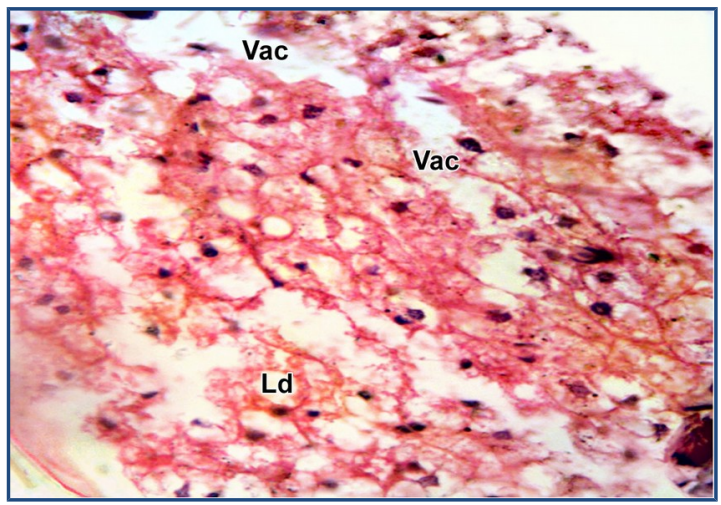

Fig. (16): Fat body of a copper-treated mature female, C. pipiens (x 100), Vac (vacuole), Ld (lipid droplet).

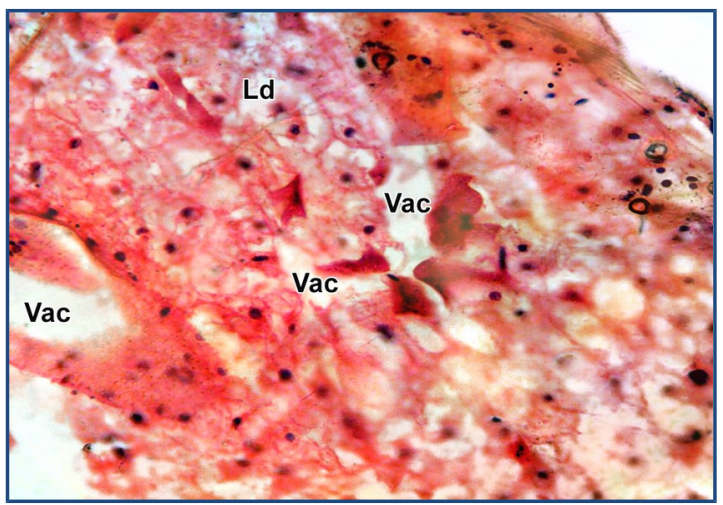


Fig. (17): Fat body of a lead-treated mature female, C. pipiens (x 100), Vac (vacuole), Ld (lipid droplet).

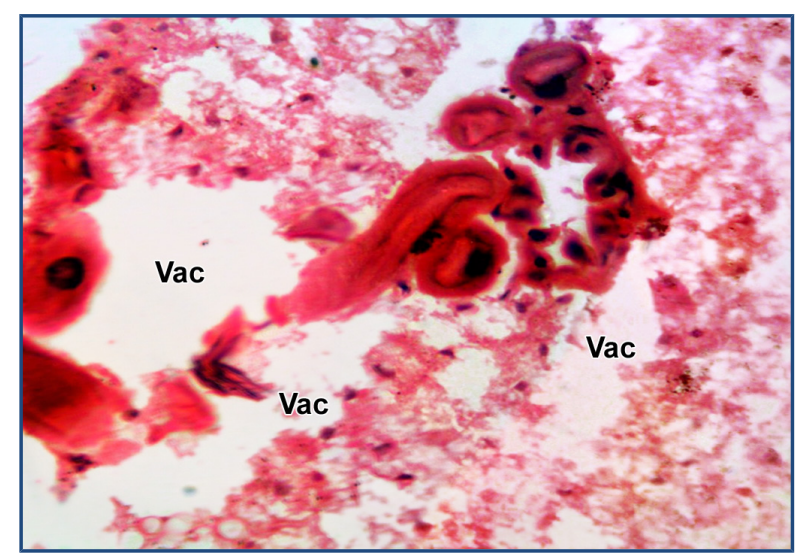

Fig. (18): Fat body of a mercury-treated mature female, C. pipiens (x 100), Vac (vacuole).

\section{References}

1. Bouquegneau, J.M.; Ballan-Dufrancais, C., and Jeanet, Y. (1985): Storage of Hg in the ileum of Blattella germanica: biochemical characterization of metallothionein. Comp. Biochem. Physiol. Comp. Pharmacol., 80: 95-98.

2. Cain, D.J.; Luoma, S.N.; Carter, J.L. and Fend, S.V. (1992): Aquatic insects as bioindicators of trace element contamination in cobble bottom rivers and streams. Can. J. Fish. Aquat. Sci., 49: 2141-2154.

3. Cervera, A., Maymo' , A.C., Sendra, M., Martınez-Pardo, R., and Garcera' , M.D., (2004):Cadmium effects on development and reproduction of Oncopeltus fasciatus (Heteroptera: Lygaeidae). J. Insect Physiol., 50: 737-749. 
4. Cervera, A., Maymo' , A.C., Martınez-Pardo, R., Garcera' , M.D., (2006): Vitellogenin polypeptide levels in one susceptible and one cadmium-resistant strain of Oncopeltus fasciatus (Heteroptera: Lygaeidae), and its role in cadmium resistance. J. Insect Physiol. 52: 158-168.

5. Clements, W.H. and Kiffney, P.M. (1994): Integrated laboratory and field approach for assessing impacts of heavy-metals at the Arkansas River, Colorado. Environ. Toxicol. Chem., 13: 397-404.

6. Dallinger, R. (1994): Invertebrate organism as biological indicator of heavy metal pollution. Appl. Biochem. Biotechnol., 48: 27-31.

7. Darwish, M. and Hoogstraal, H. (1981): Arboviruses infesting human and lower animals in Egypt. A review of thirty years of research. J. Egypt. Pub. Hlth. Assoc., 56: 1-112.

8. Devkota, B., Schmidt, G.H., (1999): Effects of heavy metals (Hg2+, Cd2+, Pb2+) during the embryonic development of Acridid grasshoppers (Insecta, Caelifera). Arch. Environ. Toxicol., 36: 405-414.

9. El-Sheikh, T. M. Y. ; Fouda, M. A. : Hassan, M. I. ; Abd-Elghaphar, A. A. and Hasaballah, A. I. (2010): Toxicological Effects of Certain Heavy Metal Ions on Culex pipiens L. (Diptera: Culicidae). Egypt. Acd. J. Biol. Sci. (Toxicology and pest control)., 2(1): 63-76.

10. Scott, T.W.; Carlk, G.C.; Lorenz, L.H.; Amerasinghe, P.H.; Reiter, P. and Edman, J.D. (1993): Detection of multiple blood feeding in Aedes aegypti (Diptera: Culicidae) during a single gonotrophic cycle using a histological technique. J. Med. Entomol., 30: 94-99.

11. Gad, A.M.; Hammad, R.E. and Farid, H.A. (1996): Uptake and development of Wuchereria bancrofti in Culex pipiens L. and Aedes caspius Pallas. J. Egypt. Soc. Parasitol., 26(2): 305-314.

12. Hare, L. (1992): Aquatic insects and trace metals: bioavailability, bioaccumulation and toxicity. Crit. Rev. Toxicol., 22: 327 -369.

13. Kasap, M. and Demirhan, O. (1992): The effect of various larval foods on the rate of adult emergence and fecundity of mosquitoes. Turkiye parazitologi Dergisi, 161: 87-97.

14. Khalil, M.; Malawani, A. and Hilmi, I.S. (1930): the transmission of Bancroftian filariasis in Egypt. J. Egypt. Med. Assoc., 15: 315-332.

15. Kohler, H.R. and Alberti, G. (1992): The effect of heavy metal stress on the intestine of Diplopods. Ber. Naturwiss-Med. Ver. Innsb., 10 (suppl.): 257-267.

16. Martoja, R.; Bouquegneau. J.M. and Verthe, C. (1983): Toxicological effects and storage of cadmium and mercury in an insect Locusta migratoria. J. Invert. Pathol., 42: 17-32. 
17. Meagan, J.M.; Khalil, G.M.; Hoogstraal, H. and Adham, F.K. (1980): Experimental transmission and field isolation studies implicating Culex pipiens as a vector of Rift Valley virus in Egypt. Am. J. Trop. Hyg., 80: 1405-1410.

18. Pelah, D.; Abramovich, Z.; Markus, A. and Wiesman, Z. (2002): The use of commercial saponin from Quillaje saponaria barks as a natural larvicidal agent against Aedes aegypti and Culex pipiens. J. Ethnopharmacol., 81 (3): 407- 409.

19. Postma, J. F. and Davids, C. (1995): Tolerance induction and life cycle changes in cadmium-exposed Chironomus riparius (Diptera) during consecutive generations. Ecotoxicol. Environ. Saf. 30: 195-202.

20. Rayms-Keller, A.; Oslon, K.E.; McGaw, M.; Oray, C.; Carbon, J.O. and Beaty, B.J. (1998): Effect of heavy metals on Aedes aegypti (Diptera: Culicidae) larvae. Ecotoxicol. Environ. Safe, 39: 41-47.

21. Wong, P. T. S. and Dixon, D. G. (1995): Bioassessment of water quality. Environ. Toxicol. water Qual. 10: 9-17.

22. Yang, R. S. H. and Rauckmann, E. J. (1987): Toxicological studies of chemical mixtures of environmental concern at the National Toxicology Program: Health effects of ground water contaminants. Toxicology 47: 15-34.

23. Zelenayora, E. (1986): Scotia segetum(Lepidoptera, Noctuidae) oogenesis affected by copper ions added to semisynthetic diet of larvae. Biologia(Bratislava) 41: 563-577.

24. Zhang, Y.; Lambiase, S.; Fasola, M.; Gandini, C.; Grigolo, A. and Laudani, U. (2001): Mortality and tissue damage by heavy metal contamination in the German cockroach, Blattella germanica (Blattaria, Blattellidae). Italian J. Zool., 68(2): 137-145. 
التأثيرات الهستوباثولوجية لبعض العناصر الثقيلة على البعوضة الناقلة للأهراض كيولكس ببينز (ثنائية الأجنحة: كيولسيدى)

\section{محمد عبد الحي فوده، مصطفى إبراهيم حسن ، طارق محمد يسرى الشيخ ، عبد الحميد عبد الفتاح عبد الغفار و أحمد إبراهيم حسب الله}

تم فى هذه الهراسة معاملة الدور اليرقى الثانى لبعوضة كيولكس بيبنز بتركيزات معينة من العناصر الثقيلة: كلوريد الكادميوم, كبريتات النحاس, نترات الرصاص و نترات الزئبق وذلك لتقدير السمية والتركيز النصف مميت لكل منها.

بعد ذلك تمت معاملة اليرقات بالتركيز النصف مميت لكل عنصر من العناصر الثقيلة لراسة تأثيره على بعض العواهل الهستولوجية على الدور اليافع الناتج من كل معاملة من المعاملات السابقة.

أظهرت الفحوصات الهستولوجية لمبايض إناثبعوضة كيولكس بيبنز المعاملة

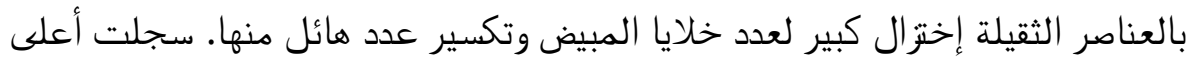
نسبة إختزال و تدمير لخلايا أمهات المنى و الخلايا المنوية فى ذكور بعوضة كيولكس بيبنز المعاملة بالعناصر الثقيلة. وكانت أعلى نسبة إختزال وتدهور مسجلة بواسطة عناصر الكادميوم والزئبق. إضافة إلى ذلك ,أظهرت النتائج الحالية تدهور الأجسام الدهنية للبعوض المعامل بالعناصر الثقيلة.

ويتضح من النتائجالمتحصل عليها فى هذه المراسة أن وجود مثل هذه العناصر في النظام البيئي المائي لبعوض الكيولكس ممكن أن تساهم في الحد من تكاثر

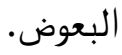


MOHAMAD A. FOUDA, et al., 
IEAVY METALS ...... 87 